\title{
PERSPECTIVES FOR A LAW OF OUTER SPACE
}

\author{
Bt Mirres S. MIODougal \\ Of the Board of Editors \\ AND \\ LEON LIPSON \\ Tale Law School
}

The conquest of space has barely begun. Yet the law of space, instead of lagging behind the astronauts as some lawyers fear, is threatening to outfly the attraction of the earth's gravity. Before legal speculation reaches escape velocity, we should perhaps remind ourselves of the specifie problems that may confront us soon, the earthly origin of much of our law, and the earthly ways in which for some time we shall have to continue to think about law in outer space.

\section{I}

Let us begin with a glimpse at the possible pattern and conditions of use of outer space and a brief mention of some of the ways in which it can now be foreseen that they may affect our thinking about events on earth, with consequences relevant for the law. ${ }^{1}$ Any attempt today to compile a definitive catalogue of the possible uses of outer space would be presumptuous. Such a catalogue would have to be open-ended and looseleaved: open-ended, because space flight itself will suggest new uses of space (as well as discourage or defer some presently contemplated uses); and loose-leaved, because the sequence in which activities are conducted in space will be a function of many variables including considerations of scientific curiosity, military-strategic policy, and cost.

I See the books and periodicals on space uses listed in Hogan, "A Guide to the Study of Space Law," P-1290, at 10-18 (Rand Corporation, MIarch 1, 1958; to be published in St. Louis Univ. L.J., Spring, 1958); Odishaw, "The Satellite Program for the International Geophysical Year," 35 Dept. of State Bulletin 280 (1956); President's Science Advisory Committee, "Introduction to Outer Space" (hereinafter cited as "Killian Report") (March 26, 1958); Berkner, "Man's Space Satellites," 14 Bulletin Atomic Scientists 106 (No. 3, March, 1958). A popular symposium treatment is given in 41 Air Force: The Magazine of American Airpower, No. 3 (March, 1958). See Also the statement of Dr. Joseph Kaplan, Chairnan, U. S. Committee for the International Geophysical Year, National Academy of Seiences, H.Rep. Comm. on Appropriations, Subcomm. on Independent Offices, Report on International Geophysical Year 20-26 (1957); statement of Dr. Richard W. Porter, Chairman, USNC-IGY Technical Panel on the Earth Satellite Program, ibid. 68-73; A. N. Nesmeianor, President of USSR Academy of Sciences, "The Problen of Creating an Artificial Earth Satellite," Prarda, June 1, 1957, p. 2. 
Among the known uses of satellites already launched, observations of the flights themselves permit inference as to the measurement of atmospheric density at pertinent heights, of the distribution of matter within the earth, and of the shape of the earth and the precise relative location of points on the earth's surface. The addition of a radio beacon emitted from a satellite makes possible the measurement of total ionization in the exosphere (a sub-layer of the atmosphere) by comparing the satellite's radio position with its optical position. Other instrumentation on the satellites has measured, for transmission to the earth, data on atmospheric temperatures, the impact of micrometeorites, and cosmic radiation of various types. On at least one satellite (Explorer III) information has been stored up in instruments and its transmission triggered by radio beams from the earth as the satellite passes over appropriate installations. The second Soviet satellite, as is well lnown, carried a dog, which survived for a week and (like other animals sent into outer space in rockets by the Soviet Union and the United States) furnished data for the planning of manned flight."

Future activities in space may be rather suggested than predicted. ${ }^{3}$ Responsible spokesmen have said that it is not too early to contemplate the use of unmanned orbital satellites for radio and television relays," for photographic observations of weather, and for photographic reconnaissance of events on the earth's surface ${ }^{5}$ rocket landings on the moon; the

2 For the fullest account so far given of the results of experiments conducted on the two Soviet satellites launched in 1957, see "Soviet Artificial Satellites of the Earth," Pravda, April 27, 1958, p. 4, giving a preliminary report, largely without numerical measurements, on measurement of orbits, atmospheric density and temperature, composition of the ionosphere, cosmic radiation, and biological effects on the dog carried in the second satellite. See also N. Y. Times, May 2, 1958.

3 Besides the sources eited in note 1, see Edson, "Astronauties and the Future," 14 Bulletin Atomic Scientists 102 (No. 3, March, 1958); Recommendations of the Technical Panel on the Earth Satellite Program of the U. S. National Committee for the International Geophysical Year, excerpted in N. Y. Times, March 20, 1958. But cf. Dr. James Van Allen, Chairman of the Working Group on Internal Instrumentation of the USNC-IGY Technical Panel on the Earth Satellite Program, National Academy of Sciences, testifying before a subcommittee of the House of Representatives in May, 1957: "I might say I do not subscribe to some 99 percent of what is written about this subject-exploration of space-as having any validity.' $\mathrm{H}$. Rep. Comm. on Appropriations, Subcomm. on Independent Offices, Report on International Geophysical Year 91 (1957).

4 Petrov, "Artificial Satellites of the Earth and the World Telecenter," Zvezda, No. 4, pp. 160, 164 (June, 1957). According to Petrov, the notion of using aircraft as relay stations for television was proposed by $P$. V. Shmakoryi in 1936.

5 The U. S. Air Foree reported in January, 1958, that it hoped to launch a military reconnaissance satellite with a recorerable capsule by the Spring of 1959: testimony of Major General Bernard A. Schriever, Commander of Air Force Ballistic Missile Division, before the Sen. Preparedness subcommittee, reported in N. Y. Times, Jan. 15, 1958. According to subsequent testimony by the same officer before the House Select Committee on Astronautics and Space Exploration, the project for the development of a reconnaissance satellite had been giren top national priority, N. Y. Times, April 25, 1958. Unidentified Air Force offeials were reported as estimating "that a reconnais. sance satellite carrying a telescope forty inches in diameter could detect objects on earth less than two feet in size from an altitude of 500 miles." Ibid. The President told the American Society of Newspaper Editors on April 17, 1958, that a reconnais: 
landing of scientific instruments on the moon in working condition; manned flight in an orbital satellite that can return its human passenger alive to the earth; manned flight to the vicinity of the moon and back; and the use of outer space for part of the trajectory of peaceful missiles, delivering (say) mail or cargo between distant points on earth. Miore remote speculation concerns the establishment of space platforms; the assembly in outer space of large craft for interplanetary exploration; modification of the earth's weather; the acquisition of economic resources now known or unknown, such as solar energy, new forms of radiation, ${ }^{6}$ and, ultimately, mineral or other resources that are present, and may conceivably become available, on the moon or other celestial bodies; and finally, discussed with all the casualness of a confident scientific era, the encounter with sentient or intelligent beings on other planets. ${ }^{7}$

The patterns of use of outer space will of course unfold in a context of conditions which even now, we suggest, can be identified as being certain to affect the law of space as it develops orer the years. Some of these conditions are common to many areas of human conduct and interest; some are, in a measure, peculiar to the use of outer space. Those that are noted below are intended to be illustrative only.

One condition of first importance is the extraordinary interdependence of scientific, military, commercial, and other objectives that may be advanced by the same activities in space. Scientific observations on cosmic radiation may some day serve as a basis for the development of radiological warfare. A television relay station may be capable of use to interfere with communications instead of facilitating them. A reconnaissance satellite may be made to yield important economic benefits from services to meteorology. Geodetic observations made by celestial mechanicians may improve the accuracy of intercontinental ballistic missiles by making international maps more precise. ${ }^{8}$ For an orbiting satellite carrying a nuclear warhead, it is perhaps not easy to imagine an immediate

sance satellite, if successful, "would transmit military information of value to all the armed forces." N. Y. Times, April 18, 1958. See also Petrov, loc. cit. note 4 above, p. 163; Edson, "Astronautics and the Future," 14 Bulletin Atomic Scientists 102 at 104-5 (No. 3, March, 1958). Some technical limitations are pointed out in Parsons, "Open Sky Plan in the Atomic Age," Missiles and Rockets 78, 80 (June, 1957); Haviland, "On Applications of the Satellite Vehiele," 26 Jet Propulsion 360, 361-362 (No. 5, Pt. 1, May, 1956) ; "USAF Pushes Pied Piper Space Vehicle," Aviation Week, Oct. 14, 1957, p. 26.

6 Counters on the two Explorer satellites launched early in 1958 have detected radiation of unexpected intensity near the apogees of their orbits. N. Y. Times, May 2, 1958 .

7 See the papers reprinted in "Man in Space: A Tool and Program for the Study of Social Change," 72 Annals N. Y. Acad. Sci. 165-214 (1958) ; Haley, "Space Law and Metalaw: A Synoptie View," paper presented at the 7th Annual Congress of the International Astronautical Federation, Sept. 19, 1956; Cox and Stoiko, Spacepower 176 (1958).

×Cf. Tumanov, "Determining the Position of a Ship by Means of an Earth Situllite," Sovetsky Flot, Dec. 21, 1957, p. 3, quoted in 9 Current Digest of the Soviet Press 23 (No. 52, 1958). 
commercial or scientific use that would not be served more efficiently by some other device, but it would be rash to say that no such use is possible.

By reason of this interdependence, it may be difficult to apply some well-known legal techniques-prohibition, conditional permission, allocation of responsibility for damage, regulation, and so on-on the basis of supposed predominant category of use. If we want certain benefits we may have to accept certain risks. Especially in the preliminary exploratory stage (which may last for generations), we may have to stress those aspects of legal control that permit and encourage development, while doing our best to measure the size of the risk to which we are being exposed. This does not mean that we ought to reject the possibility of reaching, or at least talking about, an agreement to outlaw certain uses of outer space, for the marginal gains to be expected from those uses may not be worth their price; but it does imply that it will not be easy to define "peaceful purposes" or "scientific purposes" without risk of hampering activities that have multiple uses.

A second feature in the setting is established by the relation between activities in space and the international political situation; that is, the structure of the earth arena, the position and number of Powers, their relative technological success, and expectations of violence. The only Powers that have so far (to the best of our knowledge) succeeded in throwing a ball or a can into outer space are the same two Powers around which the nations of the earth have been observed to cluster in the well-known postwar "bipolarity." In the short run, the gap between the most powerful and the least powerful nations, between the technologically most advanced and the technologically least advanced, will seem to widen, and the visible orbiting satellites furnish a spectacular evidence of the widening gap. Yet the gap will be closed, though by the time it is closed it may be obsolete to speak of competing national state systems at all. Even before that time comes, the political effects of achievement in space may be the reverse of the technological effect. As the lessons of space prowess are driven home to the peoples of the earth, the Big Two may find that they must pay not less but more attention to the reactions and drives of the less powerful nations; that they must redouble their coupled assurances of the possession of strength and the resolution not to use it except under extreme provocation; that they must pursue their quest of international support in the formal and informal fora of world public opinion. Thus, under today's conditions, each accretion of power to the two contending systems of world order, thrusting still heavier responsibilities on those who wield that power, may paradoxically increase the trend toward multipolarity, uplifting the weak and casting down the strong. This, however, is not to say that outer space is destined to be controlled by the world (earth) community or that the nation states with effective power in outer space can be expected or should be required in the interest of that community automatically to relinquish it to any particular international organization.

A third feature of the factual setting relates to the changing relative 
importance of distance and time. It is possible that achievements in space will tend to diminish the importance of space in the positional sense and increase the importance of time for the planning of human affairs. In military planning, to take one example, the threat of attack from outer space may reduce the intervals available for self-protection by shelter or by reprisal and thus increase the urgency of inspection and patrol. The importance of this fact for law is indicated by the existence of the Air Defense Identification Zones, scores of miles out over the high seas, which preceded the age of space by several years." In terms of location the underlying high seas are not United States "territory"; but in terms of time the United States has a legitimate claim, as would other nations in similar circumstances, to check on suspicious activities that are carried on so few minutes (rather than so few miles) away from American shores. ${ }^{10}$

A somewhat different aspect of the importance of time to the law of space is the interrelation of the sequences of various pertinent processes, among them the evolution of legal analysis, the course of exploration in space, the development of space technology and engineering on earth, the gradual effects of space activities on cultural attitudes, and the progress or regress of our social, political, and economic institutions. ${ }^{11}$ All these processes will take time, and their shifting concatenation will affect contemporary policy. Still another aspect of time is presented by the possibility that events on board spacecraft will be measured, so to speak, by a clock that to an observer on earth would seem to run more slowly than our terrestrial clock, and that men, like clocks, may "age" more slowly on space trips than on earth. ${ }^{12}$

\section{II}

The first few orbital satellites launched by the Soviet Union and the Inited States in connection with the International Geophysical Year would present in themselves no grave threat to international order. Yet the bare facts of the achievement are so spectacular, the implications for military technology so portentous, and the possible consequences for other domains of human action so numerous and significant and in part so urgent, ${ }^{13}$ that the volume of legal writing on control or regulation of

a Pepin, The Legal Status of the Airspace in the Light of Progress in Aviation and Astronauties 5 (1957) ; MeDougal and Burke, "Crisis in the Law of the Sea," 67 Yale Law J. 539, 583 (1958); Martial, "State Control of the Air Space Over the Territorial Sea and the Contiguous Zone," 30 Canadian Bar Rev. 245 (1952).

10 $\mathrm{Cf}$. the U. S. proposal for a zone of inspection in the Aretic, laid before the U.N. Security Council on April 29, 1958, and the counter-resolution submitted by the U.S.S.R. N. Y. Times, April 30, 1958, p. 10.

11 L. K. Frank, "Cultural Implications of Man in Space," 72 Annals N. Y. Acad. Sei. 195 (1958).

12 Killian Report, p. 7; Clarke, The Exploration of Space 176-177 (1953).

13 Objectives to be served by space exploration as expressed by governmental spokesmen in the United States and the Soviet Union have been limited to a fairly modest range. The Killian Report mentions curiosity, defense, prestige, and the zeal for scientific knowledge. The President's message to Congress dated April 2, 1958, proposing the creation of a National Aeronauties and Space Agency, was confined 
activities in space has grown rapidly. The increased testing of missiles whose trajectory reaches very high altitudes, and the possibility that such missiles fitted with nuclear warheads will soon have achieved operational capability and numbers, have contributed to the sense of urgency and to the elaboration of a spate of random proposals, extrapolated from poorly evaluated contexts and unrealistic in terms of probabilities.

Most legal writers discussing the legal regime of outer space have proceeded from absolute notions of airspace sovereignty and have felt it necessary to establish a boundary between outer space and airspace. ${ }^{14}$ They have proposed various schemes, some of which will be mentioned below, for the zonal division of space. They appear to have assumed, not always explicitly: (1) that present legal arrangements for use of conventional airspace would be unaffeeted by the arrangements adopted for outer space; (2) that the arrangements adopted for outer space must differ substantially from those adopted for airspace; (3) that outer space must have a legal "status" which could be discovered or agreed upon; ${ }^{15}$ (4) that for this purpose it was necessary to fix a single boundary in terms of location; (5) that the establishment of such a boundary was possible without serious regard to physical facts (except those used in the establishment of the boundary itself), present and future technological developments, the functions of spacecraft, or the purposes of space activities.

The problems presented by man's entry into space appear to others to offer an opportunity to fortify international organizations and expand their jurisdiction. Proposals for legal control in the altitudes above the chosen boundaries have centered round the United Nations, or some other present or proposed international organization, as preferred or even exclusive owner of outer space, operator of spacecraft, prescriber of "law" for events in space, forum for preparation of an international convention to preseribe such a "law," or research agency for outer space."1

to recommendations for administrative machinery in aid of these objectives; seo N. $\mathrm{Y}$. Times, April 3, 1958. A proposal made on March 15, 1958, by the Ministry of Foreign Affairs of the U.S.S.R. linked the use of nuclear power and the exploration of outer space and stressed the "opportunities for the joint study and harnessing of the still unexplored forces of nature" by way of preamble. N. Y. Times, March 16, 1958.

14 See the sources cited in Section $V$ below.

15 To suppose that there is a "legal status of space" involves as much reification as to suppose that there is a single "freedom of the seas." In both cases the question to be asked is, rather, What legal consequences should be entailed by certain activities in order that they be accommodated with other activities under given policies? Nor will legal analysis be advanced by distinguishing between jurisdiction over space and jurisdiction over activities in space, or by suggesting that "the first legal problem of the space age, and of most immediate concern ... is the question of who owns space." Hon. K. B. Keating (Rep., N. Y.), "The Law and the Conquest of Space," address before N. Y. State Bar Ass'n., Jan. 31, 1958, p. 6. Cf. Matéesco, "A qui appartient le milieu aérien'", 12 Rev. du Barreau de la Prov. de Québec 227, 239 (1952), concluding that the attempt to determine the legal status of airspace should be abandoned.

16 See Knauth, Legal Problems of Outer Space in Relation to the United Nations 13 (1958); Committee to Study the Organization of Peace, Strengthening the United Nations 218-219 (1957); Cooper, "Missiles and Satellites: The Law and Our National Policy," 44 A. B. A. Journal 317, 321 (1958). 
In detail the proposals have included lists of doctrinal topies that in the view of the compilers should be handled by international agreement; ${ }^{27}$ recommendations for "a permanent UN space police organization, in advance of any space dispute"; ${ }^{18}$ anticipation of "the sharing of responsibility, through the United Nations if possible, for the pacific development"' of primitive extraterrestrial populations ; ${ }^{19}$ and suggestions, advanced by Senator Wiley of Wisconsin in February, $1958,{ }^{20}$ and repeated, with slight modification but without attribution, by the Soviet Foreign Ministry in March, ${ }^{21}$ for a new international scientific organization on problems of outer space.

Later we shall attempt to offer a brief appraisal of proposed organizational arrangements for control of activities in outer space, the proposed doctrinal content of space "law," and the proposed geographical limits of its application, and to suggest by anticipation the past experience which may come to be considered most influential in the evolution of space law. Before undertaking this, we think it indispensable to survey, if only in outline, the probable specific controversies that may arise with respect to uses of outer space, that is, the claims that will be made by various participants to engage in, or prescribe or apply authority to, the use and exploitation of outer space, and the probable processes of earthbound decisions by which such controversies may be resolved. If we bear in mind also the likelihood of changes through time in all pertinent variables-the pattern of use, the relevant surrounding conditions, the character of controversies, and the processes of resolution-we may hope to arrive at an orientation and a perspective that bear some relation to reality, and to submit tentative recommendations for policies in the interest of the general community.

\section{III}

The first task is to outline the probable course of future controversy. The initial question here is: Who, in the fairly near future, will make claims to act in outer space without interference from others on the earth, to restrain others from acting in certain ways in outer space, or to preseribe and apply policy to events in outer space? Probably the principal actors will be nation states; it is they-and not many of themwho will possess the necessary rocketry and mobilize the necessary funds. Private entities within a nation state, or private entities in two or more states acting as joint adventurers, may marshal the funds necessary for

17 Jenks, "International Law and Activities in Space," 5 Int. and Comp. Law $Q$. 99, 102-112 (1956).

18 Cox, "International Control of Outer Space," Missiles and Rockets, June, 1957, p. 71.

19 Lasswell, "Men in Space," 72 Annals N. Y. Acad. Sci. 180, 191 (1958). For perceptive anticipation of some of the more important controversies, see Lasswell, “The Political Science of Science," $50 \mathrm{Am}$. Pol. Sci. Rev. 961, 971 (1956).

20 Wiley, "Challenges, Old and New, in the Space Age: The Need for an International Space Organization," address prepared for delivery at Georgetown University, Washington, D. C., Feb. 24, 1958 (mimeo.).

21 N. Y. Times, March 16, 1958. 
commercial or scientific activities in outer space, though they probably would depend upon the launching facilities of national governments. It is conceivable that an undertaking in space may be a joint effort of several types of participants: national governments might provide the launching facilities and specify certain uses of the satellite; private, commercial, or scientific organizations (national or trans-national) might finance certain uses, prepare and control some of the instrumentation, and claim some control over the resources produced by that portion of the activity that they had financed and planned. International (regional or global) organizations will also claim to be able to act in outer space, though difficulties of financing under present conditions may preclude important activity under such auspices unless new types of arrangements are devised. International organizations, as well as nation states without present launching capability, are already, of course, active in the assertion of claims to preseribe and apply poliey to events in outer space.

The objectives to be sought by these claimants will not differ, except in modality and proportion, from objectives of the same types of claimants in respect of the use of conventional airspace or the use of the sea. To the extent that the élites of the nation-state claimants can act, whether consciously or unconsciously, appropriately to maximize gains and minimize losses, they can be expected to seek to extend their power and promote their security not only by developing direct weapons uses, but also, and perhaps much more significantly, by increasing the lmowledge and skills at their disposal; by enhancing the prestige and respect that they enjoy in the community of nations; and by increasing wealth that may ultimately become available as a consequence of the enlargement of resource environment and the advance of technology. Nation states lacking an early prospect for the capacity to engage in space activity may be expected to seek protection, through alliances or action of the international community, from real or fancied threats of attack; to seek a share of whatever resources are produced by activities in space; and to seek access to the knowledge and skills developed by space activities. In a different epoch it might have been expected that some states, or some important organized forces, would react to man's entry into outer space (had that entry been possible in that epoch) by attempts to discourage the activity of others in that direction, but contemporary culture makes it unlikely that states will harbor, or at least express, attitudes of hostility, either monopolistic or obscurantist.

Some of the condititions under which these objectives will be sought by these claimants have been sketched above: the interdependence of different types of objectives, the competing trends toward bipolarity and multipolarity, and the increasing importance of the temporal dimension for the process of claim and decision. Only the course of future events can disclose the exact nature of changes that may be expected in these and other conditions, such as the progress and spread of space technology, the type and richness of the resources actually made available for exploitation in outer spaces, the possibilities of destructive impact (deliberate or 
accidental) on the earth; possibilities for surveillance of activities on the earth from space; fluctuations in effective relations between contending systems of order among states; fluctuating expectations of early or substantial violence on the earth; possibilities for defense against, or destruetion of, objects launched into outer space; and indirect consequences of space activities, like changes in the pattern of technical education, changes in the degree to which economic activity in industrialized countries becomes increasingly capital-intensive, and changing conceptions of the place of man (and of God) in the universe.

One condition of the use of space that has immediate relevance for the process of claims with respect to that use is the degree to which the resources of space, in the broadest sense of the term "resources," admit of being shared. Space can be used for the simultaneous flight of more than one craft, for instance, though in time some rules of the road will of course be needed. Scientific observations of cosmic rays, storm patterns, air density, meteor showers, and the like, can be carried on by many different satellites at the same time. Television relay stations could, apart from considerations of cost, be put up by separate and even competing Powers. The other planets in our solar system, and the moon, can at some point in time be visited by exploratory manned or unmanned rockets launched by more than one Power.

Such uses may be called sharable, or inclusive; they permit similar activity by others without the necessity of more than minor accommodation. It is true that some of the results of some of these activities cannot be shared. For example, if the planet Venus proves to be enveloped in a sea of petroleum and if a means is devised for bringing the petroleum back to the earth or for fueling vehicles with it, the same oil probably cannot be used in more than one engine. Again, pictures or other records of information obtained by reconnaissance may be transmitted to a number of different receivers or may be reserved by various devices until they reach a single intended receiver, and in some easily imaginable circumstances the value of such information-like the value of a diamond-may vary with its scarcity. Nevertheless, the underlying activity is sharable in the same way as many can fish, though the catch be severally appropriated.

Most claimants, while asserting their own rights to engage in such sharable activities, will probably acknowledge or at least not deny that others may do the same. ${ }^{22}$ Like many traditional claims in public and private international law, these claims will carry a promise of reciprocity, combined wherever possible with latent or expressed threats of retaliation or reprisal if the complementary promise is dishonored. This pattern of reciprocally tolerated access to outer space for sharable or inclusive uses may be restricted by the attempt to ensure the public order of the world community through devices providing security from military attack, pre-

22 Cf. Secretary of State Dulles, speaking at a news conference on the Soviet protests made against balloon overflights: "In the main, it is a recognized practice to avoid putting up into the air anything which could interfere with any normal use of the air by anybody else." N. Y. Times, Feb. 8, 1956. 
venting or at least making difficult the activities of unaccountable (flagless) space objects or spacecraft (to be compared with measures against piracy on the high seas), and imposing rules of the road.

The emphasis on mutual tolerance of sharable uses of outer space may seem belied by the history of activities in airspace. Low-altitude flight in the air is sharable in the same sense as is flight at higher altitudes, though there is less "room"; weather balloons can take readings without necessarily interfering with the taking of similar readings by other people's weather balloons; and so on. Yet, ever since the legal positions hardened after the end of the first World War, most underlying national states claimed for themselves the right in their discretion to exclude others, or impose conditions upon the activity of others. ${ }^{23}$ For motives of defense as well as economic protection or aggrandizement, the nations of the earth will probably continue to elaim the exclusive control of the use of their superjacent airspace. We do not expect that a pattern of the shared use of outer space will in the near future be imitated in the airspace. To the extent that conventional aviation may be superseded by space flight, the pattern of exclusivity may lose much of its importance, but this development seems to be rather far in the future, with the possible exception of postal rockets. Even for such rockets, it would seem that the consent of the "target" areas had better be obtained in advance, and the "target" state might be well advised to station its own inspector when the payload is attached to the rocket.

Thus far, in anticipation of possible future controversies, we have suggested that states will probably continue, as in the IGY, to make claims to certain sharable, inclusive uses of outer space, beyond a still undescribed territorial boundary, but that they will probably also continue to demand exclusive control of the use of superincumbent airspace. In addition, it may be expected that as technological competence advances, states will, with respect to outer space, as they have with respect to the oceans, lay claim to certain occasional exercises of exclusive authority for the protection of certain special interests, such as security, safety, health, and revenue. Claims may also be made, by or on behalf of nation states not currently possessing space capabilities, for an allocation of authority whereby sharable uses are free to all and exclusive uses are the monopoly of an organization representing the world community. Because of the necessity for distinguishing in both elaim and decision between exclusive and inclusive uses, controversies will also focus for a time upon alleged problems in fixing

23 Goedhuis, "The Air Sovereignty Concept and United States Influence on Its Future Development," 22 Journal of Air Law and Commerce 209, 211-216 (1955); Enonig, The Legal Status of Aircraft 6-9 (1956); Academy of Sciences of U.S.S.R., Institute of Law, International Law 318 (Korovin ed., in Russian, 1951); Lisovskii, International Law 158-160 (in Russian, 1955); Kislov and Krylov, "State Sovereignty in Airspace," International Affairs, No. 3, 1956, pp. 35, 36-39; Lakhtine, "Rights over the Arctic," 24 A.J.I.L. 703, 714 (1930). See the Soviet notes to the U. S. Government protesting the launching of balloons that overflew the Soviet Union, N. Y. Times, Feb. 6 and 19, 1956. 
boundaries and ultimately upon real problems in distinguishing between types of activities.

Other types of controversies can be expected to involve, inter alia: claims to share, or to exclude others from sharing, the resources yielded by exploration and research in space, whether in the form of new knowledge and skills, materials or energy derived from space exploration, access to celestial bodies, or effects produced on the earth; claims to regulate and fix responsibility for deprivations inflicted by space activities such as impact damage, ${ }^{2 *}$ intended injuries to space objects, pollution, invasion of privacy by means of reconnaissance, effects on weather, or interference with communications $;^{25}$ and later, in the era of manned space flight, claims related to the chartering and licensing of spacecraft, to the nationality or other link of spacecraft with the launching state or other organization on the earth, to the regulation of events on board spacecraft that produce consequences of importance to the legal systems of the earth, and to the control over certain aspects of any encounters with extraterrestrial life. Each type of controvery thus projected will comprise sets of opposing claims, will be affected by its own unique variables, and will require its own distinct clarification and application of policy.

\section{IV}

Having indicated some of the types of prospective controversies between the states of the earth over the use of outer space and the prescription and application of authority to uses of outer space, we turn to consider the ways in which those controversies are likely to be resolved.

The first important question is, again, Who will make the decisions? Since some of the eurrent proposals for space law seem to assume that

24 The possibility that a satellite sent into outer space could be designed to survive re.entry into denser atmosphere was raised in 1956 by Drs. Carl Gazley, Jr., and Davil J. Masson, who reported that new alloys already developed could withstand the maximum temperatures which it was expected that a satellite would attain upon descending into denser atmosphere. Time, Dec. 3, 1956; N. Y. Times, Dec. 2, 1956.

Reports that fragments of satellites already launched (Sputnik I and II) fell to earth in recorerable condition seem to be unconfirmed. At all events, writers, who supposed that a satellite, upon losing altitude, must necessarily "burn up like a meteor," might have reflected that parts of some meteors reach the earth. $C f$. "Satellite of the Earth," Agitator (a Soviet periodical), Oet. 1957, pp. 6, 9.

2s "The Federal Communications Commission... has received a formal protest that radio transmissions of the Soviet Sputniks have violated global agreements for radio frequency allocation. Under the International Telecommunications treaty, certain bands are reserved for worldwide use for distress signals and scientific purposes. The unauthorized use of these bands by the Sputniks may have resulted in serious errors of instrument calibration and interference with aircraft radio and radar beacons. This situation will be aggravated, of course, as more Sputniks and baby moons are launched. A conglomeration of satellites transmitting conflicting signals could enlanger lives and would make tracking and transmission virtually impossible." Rep. Keating, loc. cit. note 15 above, p. 9. The aceuracy of the comment is less important than the fact that the controversy has arisen. According to a Soviet report, it was in the interest of greater precision of measurement that a frequency was selected which would be less subject to ionospheric distortion. Pravda, April 27, 1958, p. 4. 
decisions will be made directly by the conscience of mankind, or by some presently mythical global court with universal compulsory jurisdiction, it may be useful to recall that the most influential participants in the process of making authoritative decisions will probably, in the large, remain the officials of nation states-not only those states with outer space capabilities, but also others. The composition of the relevant elites may change in ways that may have importance for the character of their decisions on space claims; scientists and engineers, for example, may exert greater weight in their national councils than they used to, and this change may influence national policy in a direction that may (but need not) be more universalistic and more rational. ${ }^{26}$ International officials, religious leaders, military technicians, and others may affect decisions on some space issues to a degree not equaled perhaps even by the current controversy over the production, testing, and use of nuclear weapons. Political officials and their legal advisers may find themselves faced by urgent demands for early, formal, comprehensive agreement on a wide range of issues not yet ripe for such treatment; and it may be remarked in parentheses that it will serve some of them right.

It is characteristic of the loose and primitive structure of the contemporary earth arena that many of the nation-state officials who will make the decisions are the same who will be making the claims. The difference in rôle may make a significant difference in self-image, in the length of the time range for the calculation of interest, and in recognition of need for reciprocity; but the objectives of their action as decision-makers will of course in measure overlap the objectives of their action as claimants. They will be, and they will take care to appear to be, concerned for the attainment of some modicum of security: the indefinite postponement of unacceptably destructive violence, the achievement of some stability of expectation as to modes of exercising effective power, the maintenance of public order against hostile or reckless or capricious threats. They will wish to conserve the potentially vast resources of space for the production of the largest net gain in all values, though their respective preferences for the distribution of the gain may be mutually incompatible. They will probably concur in demanding that as many of the uses of outer space as are capable of being shared without serious inconvenience be kept available for sharing. They will seek in various ways to adapt to their existing power objectives the potentialities opened up by the access to the new resource environment; the brave new worlds will not for some time suffice to redress or greatly distort the balance of the old.

The process of decision will similarly be affected by many of the same conditions that are relevant to the process of claim. The distribution of effective power (in the broadest sense) on the earth, reckoned according to numbers of participants, relative strength and leverage, scope and stability of their coalitions or alliances, and expectations of violence from various quarters, will affect the urgency and the content of decision. The

26 See Kistiakorsky, "Seience and Our Future," 60 Harvard Alumni Bulletin 548, 549 (1958). 
changing state of negotiations on disarmament with respect to ballistic missiles, nuclear weapons, and conventional forces, will affect the perceived importance of agreement on certain areas of outer space activity, the degree of expectable conformity to whatever decision is reached, and the power available to whatever entity will attempt to police the decision. The direction of space efforts and thus the relative importance of decision on various issues will be affected by the understandably growing budgetary ambitions of planners, military and civilian, lay and scientific, ${ }^{27}$ by the spur to technology given by the challenge of outer space, by the international political appeal of space prowess, and by the conscious deference of the great Powers toward the strength that resides in weakness. The need for speedy decision may be increased by the rise in the number of participants and the gravity of the consequences of action or inaction; the same factors may increase the need for concentration of decision-making functions or, in the alternative, for more successful indoctrination and procedural planning at the periphery.

In many respects the methods by which controversies over the use of outer space will be resolved in the prescription and application of policy can be expected to resemble those by which the law of the sea has evolved ; ${ }^{28}$ these have recently been deseribed in some detail and need not be rehearsed here. ${ }^{29}$ In certain important respects, however, they will differ. Thus, changes in the time factor, to which we have already alluded, may make the "intelligence" component of decision more important for the application of law in outer space and of space law on earth than it is for the law of the sea. The recommending function may, as we have suggested above, be characterized by a larger rôle for the scientist and the skilled technician. The disparity between capabilities of less and more powerful nations may precipitate new groupings for the assertion of demands in such bodies as the United Nations.

It is possible, also, that a new emphasis may be placed upon the rôle of explicit agreement in the preseription of policy. Thus, voices are being raised in urgent recommendation that new prescriptions to govern activities in outer space be elaborated by most explicit, formal, comprehensive, and early multilateral agreement. ${ }^{30}$ Among the motives of this ur-

27 The head of the U. S. Rocket and Satellite Research Panel of the IGY has testified before a Congressional committee that Congress should appropriate at least $\$ 500,000,000$ a year for the National Aeronauties and Space Agency. N. Y. Times, April 29, 1958 The President's Science Adrisory Committee referred to a rough estimate of "about a couple of billion dollars, spent over a number of years to equip ourselves to land a man on the moon and to return him safely to earth." Killian Report, p. 11.

28 Zadorozhnyi, "The Artificial Satellite and International Law," Sovetskaia Rossiia, Oct. 17,1957, p. 3.

20 McDougal and Burke, "Crisis in the Law of the Sea: Community Perspectives versus National Egoism," 67 Yale Law J. 539, 559-565 (1958).

so E.g., MIunro, "Law for the 'Heav'n's Pathless Way',", N. Y. Times Sunday Magazine, Feb. 16, 1958; Cox, "International Control of Outer Space," Mfissiles and Rockets, June, 1957 , pp. 68,71 ; B.P.-D., 'L $L$ 'apparition d'engins 'extra-atmosphériques' va exiger l'élaboration d'un 'droit international de l'éspace',' Le Monde, Oet. 12, 1957, p. 4; Aaronson, "Earth Satellites and the Law," 220 Law Times 115 (Aug. 26, 
gency, the fear of military uses probably predominates, though one may also detect the desire for doctrinal tidiness and the vague hope that by throwing a net of legal controls into the vastness of the universe one may tame the disturbing unkmown. The diverse proposals for a "Big-Solution-Now" seem to proceed upon one or more of several underlying assumptions :

(a) That paper agreements solve problems whether or not effective sanctions exist to assure compliance.

(b) That the necessary objective of negotiation is agreement.

(c) That almost any agreement is better than no agreement.

(d) That over-all solutions that fail are superior to particular adjustments that succeed.

(e) That international control, operation or ownership is somehow "demanded" by the supposed intrinsic supranationality of extraterrestrial activity or else morally superior to a "national" solution.

(f) That the supposed tidiness of an explicit comprehensive treaty or convention would be so far preferable to the uncertainty of the legal situation in the absence of such a treaty that it is worth paying a substantial price to achieve it.

These assumptions are at least debatable, and in present circumstances some of them seem plainly wrong. At all events a broad agreement of this sort is unlikely under present conditions, and hopes should not be raised if they are very likely to prove false. Particular subjects may be dealt with by formal agreement; we suggest below some of the subjects on which agreement is foreseeable, if not probable. The remainder of what a future historian will-only in that future-be entitled to call "The Law of Space," when law is conceived as the community's expectation about the ways in which authority will and should be preseribed and applied, will undoubtedly grow by the slow building of expectations, the continued aceretion of repeated instances of tolerated acts, ${ }^{31}$ the gradual development of assurance that certain things may be done under promise of reciprocity and that other things must not be done on pain of retaliation. The practice of the various makers of decisions, most of them in the foreign offices of nation states, will be guided by the experience of the past; it is in this way, and not by mechanical translation, that the two great bodies of legal experience with respect to air and the sea will become relevant.

Methods for the application of authority may also reasonably be expected to vary from those that have traditionally characterized the inter-

1955); Commission to Study the Organization of Peace, Strengthening the United Nations 218-219 (1957); Pépin, The Legal Status of the Airspace in the Light of Progress in Aviation and Astronautics 7 (1957); Danier and Saporta, "Les Satellites Artificiels," 18 Rev. Gén. de l'Air 297, 303 (1955); Peng, "Le vol à haute altitude et l'article 1 de la convention de Chicago, 1944," 12 Rev. du Barreau de la Prov. de Québec 277 (1952). Contra, Schachter, "The Law of Outer Space," address to International Law Association, American Branch, April 11, 1958 (mimeo.).

31 Until the diffusion of space technology, the number of states acting in outer space may be regarded as somewhat limited for establishing the expectations necessary to the growth of "customary law." 
actions of states. Nuch of the conerete application of community preseription to the resolution of controversies about uses of outer space will of course be made, in centuries'-old tradition, by the states themselves as against one another in supervising and regulating their own initiative and enterprises. It is probable, however, that evolving space activities, with all their promise of new richness and intensified threats, will be attended by new and more comprehensive demands for direct, organized community intervention. Demands already being asserted range over such varying degrees of community involvement as: advance registration, advance inspection, approval prior to launching; regulation of launching-time, orbits, contents, and activities; prohibition of military uses; international operation of some or all space flight; and international ownership of some or all spacecraft, as well as of space objects, things discovered, resources acquired, etcetera. In the presently unlikely event that one nation state acquires and retains overwhelming power to preseribe and enforce order in space, the decisional process will be naturally weighted in favor of that state's policies, though the power be seldom exercised, as in the maritime pax britannica of the nineteenth century. ${ }^{32}$

\section{$\mathrm{V}$}

Speculation on the outcome of controversies over the use of outer space must be muted by the awareness that no agreement in these circumstances will be worth more than the common interest of the participants, clarified either at the time of agreement or later in the course of experience under it. The fact that leaders purport to recognize such a common interest is, of course, no proof that there is one, though there may indeed be one which the leaders, despite their assurances, fail to recognize. The interdependence of the nations of the earth, already lnit by contemporary technology, will be increased, at least until (and probably even after) the remote era of extraterritorial colonization has been followed by the still more remote period of the wars of interplanetary independence. This interdependence, though pervading all values, is most apparent in the field of security. There is no present reason to suppose that by reason of eapabilities in outer space any state will become able absolutely to secure its military safety by unilateral action, while at the same time the danger of substantial military damage (not necessarily defeat) in the event of hostilities will if anything grow greater. Apprehension of possible military dangers, often exaggerated, can be expected to continue to color decisions and to impede the clarification of common interest in peaceful uses. ${ }^{33}$

Most of the published legal discussion about probable future decisions has been focused on the question whether existing prescriptions on sovereignty in airspace apply to flight in outer space. The principal text sub-

32 The policies of a dominant state need not favor claims of exclusive authority even by officials of that state; see McDougal and Burke, loc. cit. note 29 above, 566569 (1958).

$33 \mathrm{McDougal}$ and Feliciano, "International Coercion and World Public Order: The General Principles of the Law of War," 67 Yale Law J. 771 (1958). 
jected to this type of analysis is the Chicago Convention on International Civil Aviation of 1944, which uses the term "aireraft" without defining it except in annexed wording close to the formula of the Paris Convention of 1919: "all machines which can derive support in the atmosphere from reactions of the air." 34 The flight of pilotless aircraft over the territory of non-consenting states is prohibited by Article 8 of the Chicago Convention, but this provision was taken in substance from Article 15 of the Paris Convention. ${ }^{35}$

A few legal writers have taken the position that the Chicago Convention and domestic Constitutional or statutory pronouncements on sovereignty in airspace are automatically applicable to outer space..$^{36}$ The gist of their arguments is to the following effect: that the old texts referred to air, airspace, atmospheric space and aircraft only because there was no present occasion to describe specifically activities at higher altitudes, and that terms must therefore be interpreted as covering the entire range of flight; that the old texts should not be limited to whatever is now determined to be an appropriate "ceiling" for air or for atmosphere, because no one had a ceiling in mind when the existing prescriptions were formulated, and it was only by chance that terms were used which now turn out to have a ceiling; and that the first satellites in any event passed through atmospheric space for part of their orbits.

For those who have taken this position, the question of boundaries between airspace and outerspace is not so much a question of creating new authority to fill a void as it is of changing existing authority, already supposedly projected to the ends of the universe.

A rather larger number of writers have taken the position that the existing prescriptions on sovereignty in airspace cannot be applied to flight at altitudes where there is no air-or, as some take the trouble to put it, at altitudes where there is not enough air to sustain the flight of aireraft. ${ }^{37}$

34 International Convention Relating to the Regulation of Aerial Narigation (Oct. 13, 1919), Annex A, Preliminary Section; Convention on International Civil Aviation (Dec. 7, 1944), Annex H, Def. (a).

35 International Conrention Relating to the Regulation of Aerial Navigation (Oct. 13, 1919), Art. 15 (as modified 1929); see also 2 Proceedings of the International Civil Aviation Conference, Chicago, 1944, p. 1382 (1949).

36 E.g., Danier and Saporta, loc. cit. 297, 300; Sulzberger, "Air ,Space-A Need for Definition is Seen, But an Ancient Roman Maxim Goes Begging," N. Y. Times, Feb. 24, 1958; Peng, loc. cit. note 30 above, 292.

37 E.g., Pépin, loc. cit. note 30 above, p. 3; Cheng, "Recent Derelopments in Air Law," 9 Current Leg. Problems 208, 215 (1956); Ward, "Projecting the Law of the Sea into the Law of Space," JAG Journal, March, 1957, pp. 1, 5; Roy, "Some Cur. rent Considerations Affecting the Evolution of Space Law," Am. Rocket Soc. Pub. 388-57 (mimeo., 1957). Zadorozhnyi, loc. cit. note 28 above, states: "The Soriet arti. ficial earth satellite does not violate the air sovereignty of any state if only because it does not fly in space over other states but the territory of these states by dint of the rotation of the earth passes as it were underneath the orbit of movement of the satellite, which orbit is constant in relation to the earth and stars." $C f$. Haber, "Space Satel. lites, Tools of Earth Research," 109 National Geographic Magazine 486, 495 (1956): "Satellite Appears to Roam the Globe, Which Actually Rotates Beneath It . . . a satellite's orbit will remain undeviating though the spinning world changes its face from the Americas to Africa." 
A few observers ${ }^{38}$ have supported the same position by other reasons, which may be summarized as follows:

The old texts were prepared not for the purpose of controlling or dealing with flight in outer space but for the purpose of controlling and dealing with conventional flight, especially for the purpose of anticipated postwar civil aviation.

It is unwise to warp these texts to fit automatically a new and unforeseen situation, whether or not the old terms may be made verbally applicable.

Many fechnical facts bearing on space flight-such as velocity, altitude, velocity in relation to the rotation of the earth, methods of control and guidance-as well as military and commercial possibilities, differ so widely from the corresponding facets of the problems deal with in 1919 and 1944 as to preclude the old solutions from being automatically applicable.

Co-operation of some states and the acquiescence of others in the arrangements for the International Geophysical Year, which included plans of the United States and the Soviet Union to launch artificial satellites for scientific purposes, proved either that the consent of "underlying" states was unnecessary for flight in outer space or that such consent had been granted, at least as to activities of the kind contemplated within the IGY. ${ }^{39}$

When writers in all these groups have turned from attempts to describe the results of previous decisions and begun to advance suggestions for a legal regime of space flight in the future, nearly all of them have sought, for the purpose of allocating competence over exclusive and inclusive uses, to divide outer space into fixed boundaries: boundaries fixed not by imaginary curtains vertically projected from national borders on the earth, but by equally imaginary horizontal sheets placed at stated altitudes parallel to the earth's surface. Everything under the sheet would be airspace, in which the rules of exclusive sovereignty would continue to prevail in national compartments confined by the border curtains; everything over the sheet would be "free" for all nations. The fascinating exercise of fixing the location of the sheet has been performed differently by different writers, and this exercise continues even now. Some would place it as low as

38 E.g., Meyer, "Rechtliche Probleme des Weltraumflugs," 2 Zeitschr. für Iuftrecht 31, 32-33 (1953); Jenks, "International Law and Activities in Space," 5 Int. and Comp. Law Q. 99, 103 (1956); Jacobini, "Problems of High Altitude or Space Jurisdiction," 6 Western Pol. Q. 680 (1953). RoJ, loc. cit., also mentions reasons of this order.

so An implied general consent to use of outer space for any and all purposes can scarcely be derived from express consent to uses connected with the IGY. Indeed such express consent might perhaps be reasonably interpreted as limiting such inference, at least beyond uses of the same type and under similar auspices as the IGY uses. 
thirty miles; ${ }^{40}$ others, at fifty or fifty-three; ${ }^{41}$ others as high as two thousand. Some would fix the sheet with reference not to a stated number of miles but to a supposed physical constant like "the point where the earth's gravitational effect ceases," ${ }^{42}$ which cannot mean what it seems to say; or the point where there ceases to be air or where there ceases to be enough air to sustain the flight of aircraft.

Some have suggested two sheets instead of one, to yield three zones instead of two. The most distinguished American authority on the law of flight, Professor John C. Cooper, arrived at this position in the course of a substantial evolution of ideas which the readers of his articles may trace. In July, 1951, Professor Cooper canvassed, though he disparaged, the possibility that a state's territory might extend to an altitude of 161,000 miles, which he reported as the point at which a rocket that had attained escape velocity "would leave the earth's area of attraction and pass into the gravitation control of the sun." 43 He considered that this point would be the extreme limit of state sovereignty under what he called the old classic legal theory, based on the right and duty of self-protection. The lower extreme of the range within which the boundary of state sovereignty might be fixed, Professor Cooper considered, was the upper limit of the "airspace," which he appeared to suggest was at an altitude of 60 miles. Within the range of 160,940 miles thus defined, he suggested that in the absence of international agreement the rule should perhaps be

that at any particular time the territory of each State extends upward into space as far as then scientific progress of any State in the international community permits such State to control space above it. ${ }^{44}$

In April, 1956, Professor Cooper announced that he had abandoned this rule, convinced "of the existence of almost insuperable difficulties" in its application. He stated that an international agreement was necessary "to solve the questions as to the legal status of areas above those covered by a strict construction of Article I of the Chicago Convention," and that there might be an area of "territorial space" under the sovereignty of the subjacent state "up to the height where 'aircraft' as now defined, may be operated"; then a second zone, "contiguous space," which would extend from the top of "territorial space" to 300 miles above the earth, and would also be under national sovereignty but would be subject to "a right of

40 Murphy, "Air Sovereignty Considerations in Terms of Outer Space," 19 Ala. Lawyer 11 (1958).

41 See N. Y. Times, Feb. 23, 1958; Cooper, "Missiles and Satellites: The Law and Our National Policy," 44 A. B. A. Journal 317, 320 (1958) (noting suggestions by Haley and others); Simpson, Space Law and the Practicing Attorney 9 (1958). For Hingorani, "An Attempt to Determine Sovereignty in Upper Space," 26 U. of Kansas City Law Rev. 5, 11-12 (1957), not even the sky is the limit. He would have all flight instrumentalities "subject to existing rules and regulations, no matter at what height they float."

42 Draper, "Satellites and Sovereignty," JAG Journal, Sept.-Oct. 1956, pp. 23-24.

43 Cooper, "High Altitude Flight and National Sovereignty," 4 Int. Law Q. 411, 416 (1951).

44 Ibid. at 418 . 
transit . . . for all non-military flight instrumentalities when ascending or descending"; and finally, all space above contiguous space, which would be "free for the passage of all instrumentalities." 45

Under the pressure of scientific events the suggestion has been still further refined. In September, 1957, in the light of new claims about the height reached by the Soviet ICBM, Professor Cooper warned that "obviously no neutral State can permit the space above to be used as an area for the passage of guided missiles designed to cause destruction in a distant State," and that provisions would have to be made in international agreements "for national sovereignty upwards to include such parts of space as may be required so that neutrality is preserved in any event." 46 This suggestion appears to have contemplated the extension of national sovereignty by agreement up to six hundred miles, which was the height that had been claimed for the Soviet ICBM. ${ }^{\star 7}$

Still later, a dilemma for the zonal theory was created by the announcement of the characteristics of an experimental American aircraft to be known as the $X-15$, in which manned flight would be possible for the same vehicle, to and fro, both in space that would have to be called airspace under any of Professor Cooper's definitions and in space that would be called something else. According to an address delivered on Washington's Birthday of this year, Professor Cooper would now simply register the fact that "rockets, high altitude guided missiles, satellites, and future spaceships are not aircraft . . ."; that "states have sovereignty in the air space above their surface territories and the right to control flight therein . . ."; and that

no agreement exists as to where the boundary is between the territorial airspace of a state and outer space beyond-nor as to the legal status of the intermediate area ... in which ... the presence of a certain amount of gaseous atmosphere may cause the fall of flight instrumentalities. ...48

One is led to wonder whether, if Professor Cooper's experience and ingenuity have proved unequal to the task of defining the boundaries of airspace and outer space in static zonal terms, the task is really possible or even worthy of accomplishment. Other efforts to arrive at boundary definitions as functions of altitudes, mass, velocity, heat resistance, and other physical variables combined, seem more technically sophisticated and might survive a little longer in the progress of seientific knowledge and engineering technology. ${ }^{49}$ Yet such frontiers might prove to be vulnerable to just such versatile transitional devices as the $X-15$, and it may

45 Cooper, "Legal Problems of Upper Space," 1956 Proceedings, American Society of International Law 85 , at 91.

46 London Times, Sept. 2, 1957, p. 9.

47 Cooper, "Flight-Space and the Satellites," 7 Int. and Comp. Law Q. 82, 90 (1958).

48 Cooper, "Missiles and Satellites: The Law and Our National Policy," 44 A. B. A. Journal 317, 321 (1958).

49 See, e.g., Haley, "Space Law-The Development of Jurisdictional Concepts," Address to International Astronautical Federation, October, 1957 (mimeo., Am. Rocket Soc.). 
be questioned whether they are as relevant for the purposes of human control and planning as would be an arrangement based upon types of spaceeraft, probable functions, and potential dangers. Physical characteristics would of course enter into any judgment, but they could not be the only factors.

As the Chief of Staff of the United States Air Force has said,

In discussing air and space, it should be recognized that there is no division, per se, between the two. For all practical purposes air and space merge, forming a continuous and indivisible field of operation. ${ }^{30}$

The General may have had more than one reason for putting it this way, but the truth of his statement is independent of the outcome of the controversy among the branches of the military service over control of United States defense activities in space.

In identifying the claims that will be made to the use of outer space we have suggested a distinction between sharable or inclusive uses and unsharable or exclusive uses of outer space, and have pointed out that claims to exclusive use of the airspace will probably continue to be made and defended under the label of sovereignty. Probably a general principle of "freedom of outer space" for inclusive, peaceful purposes will be fairly easily accepted and honored in authoritative decision; but for a time, at least, states will continue, for the better protection and control of activities on their land masses, to be indulged in their claims for exclusive uses of "airspace."

For distinguishing between these two competences-inclusive in outer space and exclusive in airspace-reference will undoubtedly also for a time continue to be made to some supposed boundary line, perhaps a line with a vague and shifting geographic reference as with the $x$-mile limit of territorial waters or the headland-to-headland lines of bays. ${ }^{51}$ Eventually, however, with growing awareness of the diffeulties entailed by "fixed lines" or putative horizontal sheets and of the factors that do and should affect policy, the problem will transform itself from one of boundaries to one of activities, in an appropriate pattern of reciprocities and (potential) retaliations; and the now vexed question of the legal "status" of outer space will be discarded for practical purposes, as the question of "status" was discarded when negotiations on the use of airspace came to the point of concrete agreement.

It may be expected also that claims to occasional exclusive uses even in outer space will be honored if their frequency and importance are kept reasonably low. Certainly, in the absence of general agreement and community institutions to restrict inclusive uses to peaceful purposes, states will continue to assert, within the limits of their effective power, a unilateral competence to police or destroy space objects regarded as impermissibly

50 White, "Air and Space are Indivisible," Air Force Magazine, March, 1958, p. 40 at 41.

51 MeDougal and Burke, loc. cit. note 29 above, at 574-580. 
affecting the security of their land masses. ${ }^{52}$ With respect to the oceans, assertion of such unilateral competence has been made and accepted for many purposes, including the protection of health, revenue, internal monopolies, and so on. Conceivably, a similar development in demand and reciprocal tolerance for a variety of purposes may occur with respect to outer space.

In any event, we should not expect to see a patchwork quilt of outer space like the patchwork quilt of contiguous maritime zones, because the pertinent distinctions will not be spatial distinctions. It will be relatively immaterial whether a man-launched object in outer space happens to be "above" the territory of the affected state at the moment when the offending activity is carried out, at the moment when orders for the offending activity are transmitted by electronic guidance from the earth or from some other station, or indeed at the moment when protective action is taken. For example, there can be some activities in outer space that, while they require line-of-sight connection with the relevant area on the earth, do not require that the particular line-of-sight remain within the projected vertical boundaries enclosing that area. Or, again, if something is dropped or pushed from outer space and falls on a given area on the earth, it is not a necessary incident that the spiral descent have commenced at a point "above" that area. Thus the counterpart in outer space of contiguous zones in maritime law is likely to be phrased, as indeed it is coming to be characterized in maritime law, in terms of type of activity and relevant intervals of time rather than in terms of location.

The resolution of other types of controversies over the use of outer space can be expected to draw upon past experience in the administration of activities regarded as comparable, appraising success and failure and projecting appropriate poliey. Thus, control over the identification of space objects and the location of national responsibility for them as a preliminary to allocating the burdens and benefits of space activities may become a live problem if launchings become less highly publicized and so numerous as to outstrip the capacity of the tracking stations, if objects launched into space survive re-entry into the atmosphere and strike the earth or do other damage, if spacecraft on re-entry are retrieved by a state upon which another makes a claim as the owner or launcher, and if a spacecraft ever attains the ability to wrest economically valuable resources from another spacecraft. Here experience speaks in darkening voice. The problem of registration of vehicles financed by private entities has obviously not been solved in the law of the sea, where the necessity of a "genuine link" between the country of flag of registration and the nationality of private owners is

62 An activity in space might have some military value without affecting security to an impermissible degree. Among the factors to be considered are the character and importance of other values served by the activity, and the character and importance of the military threat. A telescopic satellite, for example, which might observe clouds, stars, or earth terrain, might well be deemed to present too small a threat, by comparison to its orer-all utility, to justify any punitive action. 
still warmly debated.53 For rules of navigation, roughly adaptable models are available from the law of the sea and the law of airspace; similar principles, differing greatly in detailed application, may help in the co-ordination of launching times and flight plans, which will become important much sooner than navigation in the familiar sense.

Regulation and characterization of events on board spacecraft, a remoter problem, may similarly be analyzed and administered in ways familiar to those who have dealt with the analysis of events on ships and aireraft. The well-known competing principles of jurisdietion-nationality of the participants, territoriality (registration of the vehicle), protection of proximately affected nations (protective principle and principle of passive personality), as well as all the complementary principles in terms of "immunities" and "acts of state" by which jurisdiction is yielded-may all become relevant. These doctrines both permit any state substantially affected to assert its competence, when it has effective control over persons or assets, and afford sufficient alternatives in choice to encourage flexible accommodation in reciprocal demand and mutual tolerance. ${ }^{54}$ The difficulty that states have had in regarding the pattern of practices developed with respect to events on board ship as transferable to the control of events on board aircraft ${ }^{55}$ suggests that there may be difficulty in adopting either analogy directly for events on spacecraft. Detailed discussion of this may await the advent or more particular anticipation of concrete problems.

Despite the picturesque opportunities that the subject presents to imagination, it is probably equally premature to attempt to clarify in detail modes of redress for deprivation inflicted by space activities. The analysts of torts and delicts are already fairly skilled in weighing the interest in protection from injury against the need to foster initiative, the relevance of the fault of the various actors, the gravity of the harm that may occur, the probability of its occurrence, the cost of averting such oceurrences and the efficacy of safety measures, and the rather more complex problems of the proper incidence of the various costs involved. Whether a rule of absolute liability would be preferable to some sort of fault liability; whether there is a place for public or private or mixed insurance schemes; whether an international fund might be set up to accommodate worthy claims; whether efforts should be made to reach international agreement on limits of liability-these questions may abide

53 See Briggs (ed.), The Law of Nations 330-333 (2d ed., 1952); N. Y. Times, April 9, 1958, p. 66; Rienow, The Test of the Nationality of a Merchant Vessel (1937).

54 Moursi, Conflict in the Jurisdiction of Courts of Different States to Deal witl Acts and Occurrences on Board Aircraft (dissertation on file in Tale Law Library, 1955) ; Intema, "The Historie Bases of Private International Law," 2 Am. J. Comp. Law 247 (1953). Aireraft have presented a number of special difficulties with respect to problems of investigation, obtaining witnesses, providing for convenience of parties, and in determining the territorial location of erents in controversy, with suggestions of possible allocations of authority to states of last departure and first landing. Events on board spacecraft may evoke or occasion similar difficulties in aggravated form, though the responses may be different.

55 Cooper, The Legal Status of Aircraft 61 (mimeo., 1949); see 17 Journal of Air Law and Commerce 292 (1950). 
further experience. The nearest relevant analogy may be the problems now beginning to be posed by the use of atomic reactor machinery and nuclear material.

Questions relating to occupation of territory in outer space and exclusive claims to new resources have again been much mooted. Among the disputants there appears some disposition to believe that particular doctrines, thought to express the state of the law of occupation on earth, will be automatically applied to extraterritorial exploration unless some agreement otherwise is reached; ${ }^{56}$ but this apprehensive notion exalts the letter above the spirit. The details of any applied doctrine of occupation have always varied with relevant circumstances of technology, possibilities of effective occupation, difficulties of proof, and objectives of the participants. The policies behind the traditional doctrines on this subject derived from Roman law are, it may be recalled, to reward priority in time, to acknowledge effectiveness of control, to maintain peaceful activity and public order, and to encourage the use of territory once explored or resources once developed. The history of application of the law of oceupation and allocation of resources over the centuries, including the division of the continents of the New World and the inconclusive but instructive story of Antaretica, ${ }^{57}$ gives no ground to suppose, for example, that the moon will become American or Soviet "property" if only the Stars and Stripes, or the Hammer and Sickle, are shot onto its surface.

\section{$\nabla I$}

A durable agreement by explicit international convention on anything like a code of law for outer space is not, in our opinion, something now to be expected ${ }^{58}$ or desired. One may indeed expect with rather more confidence a series of agreements, gradually arrived at, on particular subjects, such as the continuation of the International Geophysical Year;

so The extreme illustration is provided in a popular article by Huss, 'Let's Claim the Moon-Now!" Mechanix Illustrated, Feb.-March, 1957, pp. 70, 72: "Columbus stuck the Spanish Flag into the sands of a West Indies beach-and we or the Russians would be perfectly within the concept of international law to claim possession of the Moon by shooting our national flag there by rocket."'

57 See Carl, "International Law-Claims to Sovereignty: Antaretica," 28 So. Cal. Law Rer. 386 (1955); Toma, "Soviet Attitude Towards the Acquisition of Territorial Sovereignty in the Antarctic," 50 A.J.I.L. 611 (1956). In May, 1958, the United States proposed to eleven other states a treaty for "freedom of scientific investigation throughout Antarctica," continuation of the international co-operation after the end of the IGY, and agreement "to insure that Antarctica be used for peaceful purposes ouly." N. Y. Times, May 4, 1958, Sec. 1, p. 19. Cf. Danier, "Les Voyages Interplańtaires et le Droit," 15 Rev. Gén de 1'Air 422, 425 (1952); Schachter, "Who Owns the Universe?' Colliers, March 22, 1952, p. 36. The United States proposal on Antarctica may perhaps be considered a trial balloon (launched in a polar orbit) for outer space.

58 States that have not been able to agree upon the width of territorial sea can hardly be expected fully to clarify a common interest in the allocation and regulation of uses of outer space. See N. Y. Times, April 26, 1958, p. 38: "No Sea Limit Set by 2-Month Talk." 
the exchange of certain types of information, such as tracking data and some signaling codes, beyond present levels; the use or abstention from use of certain radio frequencies; and the co-ordination of launching schedules. Particular projects, like the establishment of television or radio relay satellites, might (in addition to whatever economic or scientific merits they possess) serve to test the possibilities of broad international co-operation more fruitfully than conferences on "the law of space." Agreement might be reached-not necessarily by the execution of formal documents-to abstain from the pollution of space by shrapnel or other "junk," which might otherwise be thrown up in an attempt to impede the flight of hostile satellites or hostile communications; such agreement would probably depend on the assurance either that other means of averting the danger from the hostile activities were adequate or that the activities did not present a danger sufficiently great to justify the pollution.

The modes of reaching such agreements cannot now be charted with any precision. Some agreements may be explicit and formal; some may be simply a consensus achieved by the gradual accretion of custom from repeated instances of mutual toleration. Some may be bilateral, others trilateral or multilateral; some may be within the framework of the United Nations, others within some other existing organization or some machinery yet to be set up. Their details and sequence must, like much else in an indeterminate universe, depend on the order of experience in space as well as on the changing political context.

We recognize, however, that the order of that experience will in turn be affected by expectations which decision-making officials in the nation states possessing space capabilities entertain as to the space plans of others, and by the reactions and attitudes of the earth community. In order to help allay anxieties about the possible weapons uses of space satellites and to help lay a foundation for eloser co-operation in peaceful activities in space for common benefit-a co-operation from which an adequate and effective customary or conventional law might eventually emerge-the following suggestions might even now be considered by responsible officials :

(1) It was suggested in this JourNal early in 1957 that each state about to launch a satellite could register its intent to do so with an international agency, fling a flight plan and a description of certain characteristies of the satellite, such as load, weight, and size. ${ }^{59}$ This could be combined with willingness to submit to international inspection, to assure that the payload conforms to the description filed. This suggestion could be put into practice by any state, regardless of the agreement of any other state; but the decision to do so might well be affected by the communicated willingness of other launching states to agree to corresponding measures.

(2) Agreement might be reached to abstain from the launching of satellites fitted with nuelear or other explosive warheads. Such an agreement probably would have to be contingent on the availability of effective

$59 \mathrm{McDougal}$, "Artificial Satellites: A Modest Proposal," 51 A.J.I.I. 74, 77 (1957). 
pre-launching inspection of the type that is illustrated by the first proposal above. Whether it should or could be coupled with an agreement on the prohibition of the use of intercontinental ballistic missiles, and whether it should or could be considered as part of a possible general agreement on nuclear or universal disarmament, are matters of strategy, community and national, dependent upon the course of many variables.

(3) States possessing the capability of launching satellites might offer to launch certain types of satellites on behalf of, or even as trustee for, the United Nations. The launching state could retain responsibility for the launching operation, preserving control over the security of its rocketry; the United Nations would decide upon the purpose of the flight, determine the payload, design the instrumentation, and finance the construction of the satellite and its contents. The necessary United Nations decisions could be made by an arm of the United Nations, or authority to make them could be delegated to the launching state or conceivably to some other agent. The existence of such "trust satellites" would not necessarily preclude national satellites with similar or identical functions. 